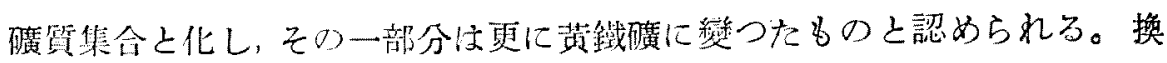

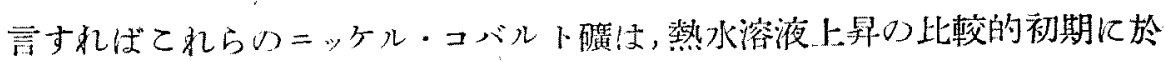
て、それから生じたものである。

要 約

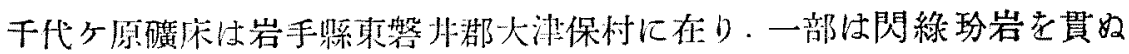
き，一部はこれに接する三㴓紀砂岩中に礦染する。磺石は主として带銅磺，

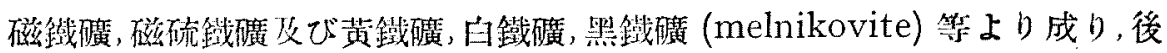
3の者は主として磁硫鐵磧の變成物と認められる。ニッケル及びュバルト

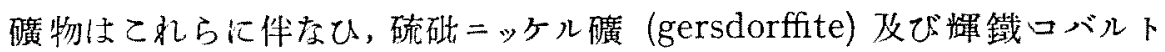
磺(ferrocobaltite)として產し，これに件志ふ二次的角閃石，石英，綠泥石及

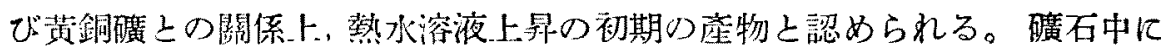
はニッケル凡そ $2 \%$ ，またはコバルト $4 \%$ を含さるのもあるが，現在まで の探礦によれば，礦床の規模小さいため，これを利肪に供するに至らぬ。切 に今後の没展定析る。

本研究に要せる费用の一部分は，文部省自然科學研究费として筆者に支給せら れたものの一部分である。ここに明記して謝意を表する。

\title{
御齋所街道石住産角閃岩中の透輝石一綠策石胍に於ける 透輝石及び角閃石の一光學的方位閣係
}

A relation between optical orientations of diopside and hornblende in some metamorphic rock from the Abukuma district.

理學揁士 大 菻 䁈 一 ( K. Ohmori)

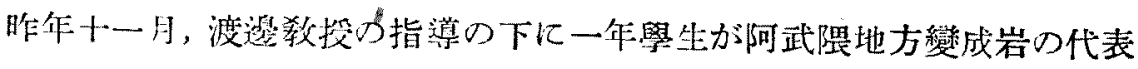

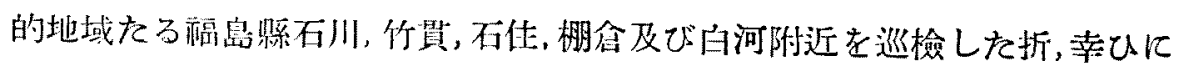

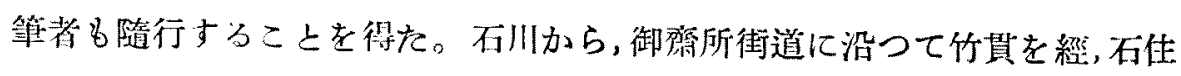




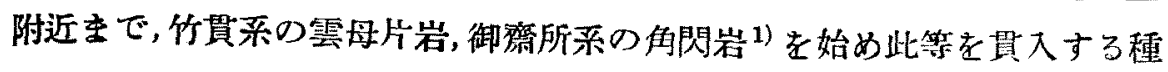
ネの岩脈を觀察した。この角閃岩は石仕附近に好露出がある。こ小に本岩 の㙷微鏡下の觀察結果の一部を簡單に報告する。詳細な研究は佮續行中で ある。

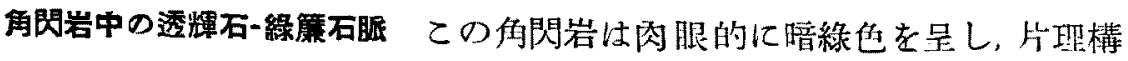
造の顯著な緻密な岩石である。肉腿的に触閉石が認められる。影微鏡下に 生角閃石，科長石，磁鐵矌及でチタン石が認められ，此等各磺物混比を Rosiwal 法 ${ }^{2)}$ で測定するに，大略头《 $79.0 \%, 16.8 \% ， 2.5 \%$ 及び $1.7 \%$ を得た。角閃石は線色を呈し，長さ䄪０.5 粆，斜長石は約 0.05 籷で屈折率 はカナダバルサムより高く，二軸性正の光學性を示す。

第壹圖

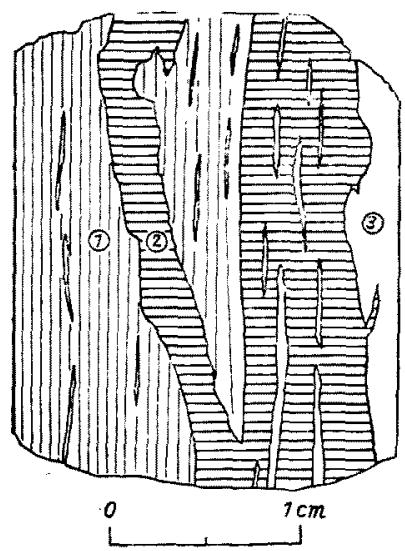

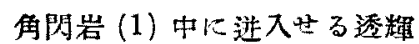
石脈 (2)を示す。(3)は (2)の 中央部の石英に富む部分であ 万。
第方 圖

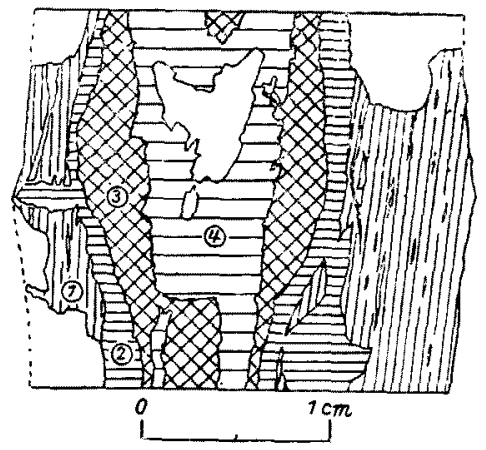

角閉岩（1）中に迷入西透辉石

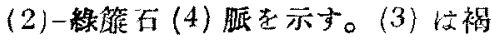
践䂾にして，(4) の中央部に孔䏚吕 ある。

1) Kotô, B., The archean formation of the Abukuma Plateau. Journ. Coll. Sci. Imp. Uni. Tôkyô. 5, 197 294, 1893.

Sugi, K., A preliminary study on the metamorphic rocks of southern Abukuma Plateau. Jap. Journ. Geol. 12, 115 151, 1935.

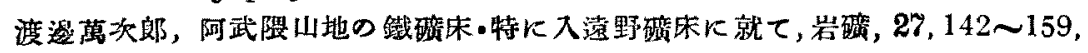
昭 17.

2) Johannsen, A, Manual of petrographic methods. 290, 1918. 


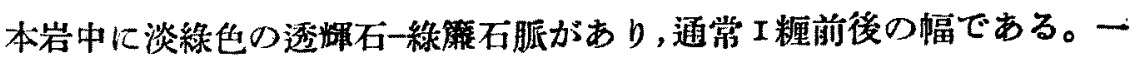
般に角閃岩の片理に平行に走つてるるが，斜に之を切つた部分 (第壹圖) 叉 は垂㨁にこの中に侵入する部分(第武圖の左方) むある。依つてての脈は角 閃岩の一部ではなく，例へば熱水溶液の进入作用等に基くるのな榚に考へ られる。

この脈を更に詳細に觀察すると，外部と內部とで色が異なり，夫ネ淡綠色

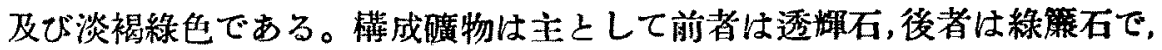
乙の兩者の間に暗褐色の褐鐵碛1)の存在する場合もある。綠策石に富む部” 分は他に少量の斜長石を含有する。この斜長石は一般に聚片双晶を呈する が,簡單な累帶丵造を示す時もるる。光學性は二軸性正で, 屈折率はバルサ ムより高い。綠策石は薄片にて淡带色を呈し，多色性が少しく認められる。 斜消光，二軸性負の光學性を示し，光軸角は極めて大である。屈折率を浸液 法で測定し， $\gamma^{\prime}=\mathrm{I} \cdot 755$ 及び $\beta=\mathrm{I} .748$ を得た。

透輝石 ${ }^{2)}$ は薄片で極めて淡い綠色を呈し，角閃岩に接觸する部分の方が 脈の內部よりも結晶が小さい。屈折率は角閃石に近似し,斜消光，二軸性正 の光學性を示す。消光角は $\mathrm{c} \wedge Z=42^{\circ}$ で，光軸角は經緯㫷臺で测定し， $2 \mathrm{~V}=60^{\circ}$ 得た。

解閃石は濃綠色を呈し，多色性顯著で, 斜消光, 二軸性負である。消光角 はc $\wedge Z=20^{\circ}$ で光軸角は經緯鏡歖で $2 \mathrm{~V}=66^{\circ}$ を得た。

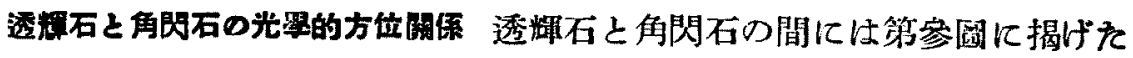
㥞な漸移關係が見られる。同圖Ｉに於ては角閃石の端緣が，2に於ては中 央部が著しく又內部及び周緗の一部が，更に3に於ては周緣より內部交で

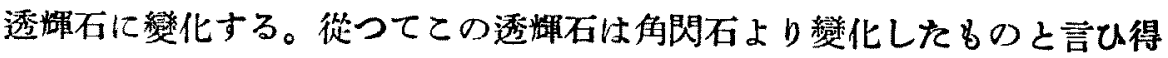
よう。

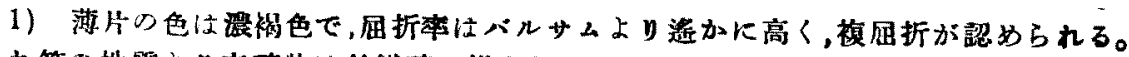
これ等の性馆上り本嘫物は針鐵碳と推される。

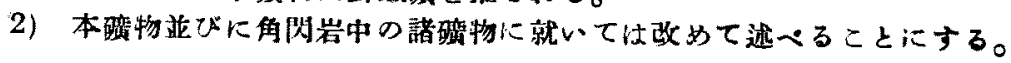




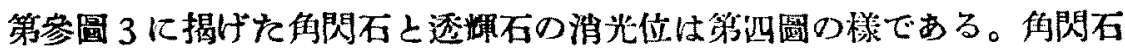
に於ては直消光を，透辉石に於ては科消光を呈する。この雨種磺物の光學 的彈性軸の經緯鏡臺に位る测定值は第䝁表に揭げた㥞である。こいに透輝

第 圖

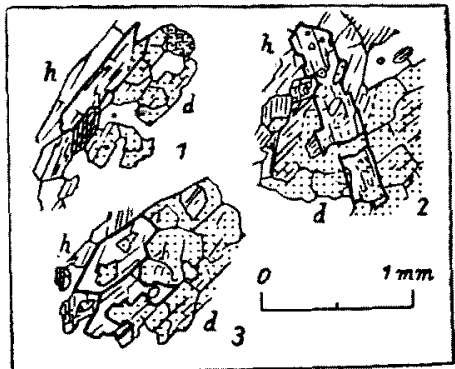

角閃石 (h) 上り透䊒石 (d)

に㷊化せる狀態を示す。
弟四固

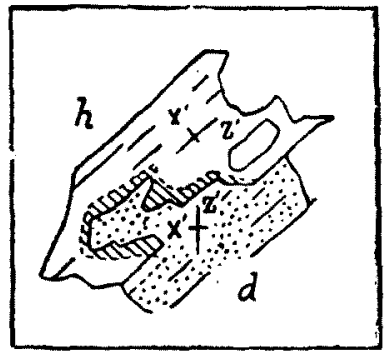

第悬路 3 の消光位上 $\mathrm{X}^{\prime}$ 及げ

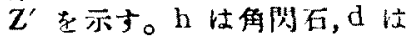

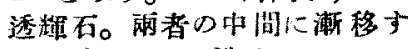
る部分があり，消光しない。

第壹表

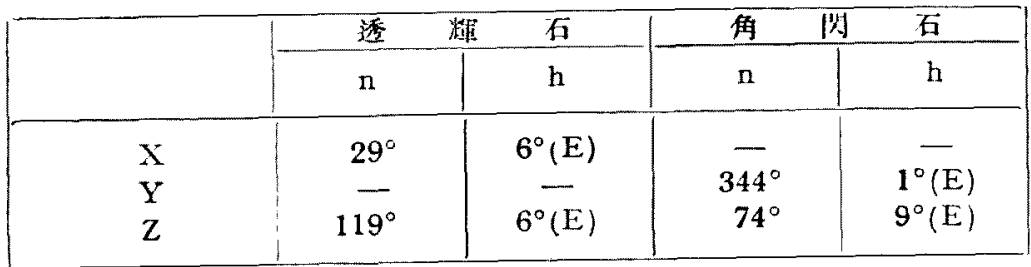

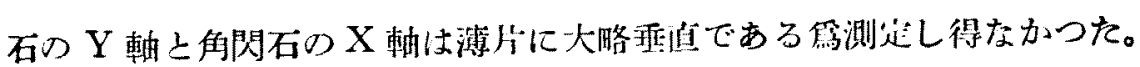

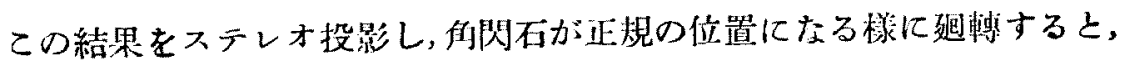

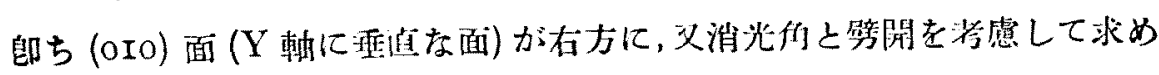
たc軸の位置が中央になる柡にすると第五圆に揭げた梯になる。

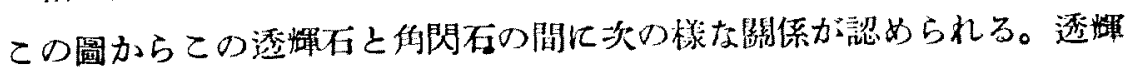
石の $\mathrm{c}$ 軸は角閃石の $\mathrm{Z}$ 軸と大略一玫する。又前者の $\mathrm{Y}$ 軸は後者の X 軸

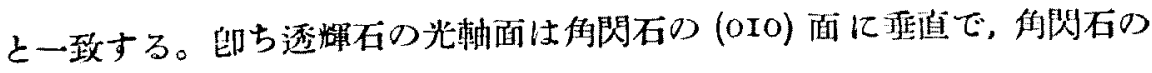

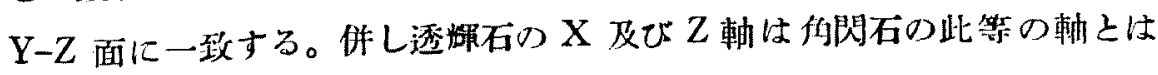




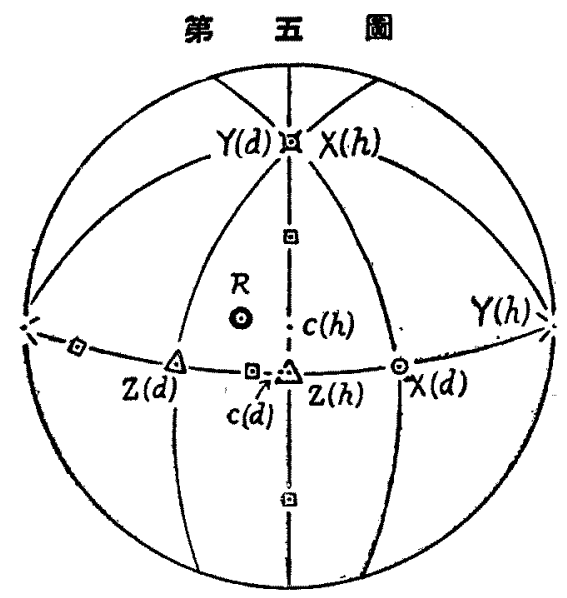

透輝石 (d) 上觕刚死 (h)の光學的方位關 㮇考示す ( $\mathrm{R}$ は迴轉軸)。
一致せず，何れも $45^{\circ}$ 離れた方向 である。念の爲にこの光朝の位置 から Biot-Fresnel の法则を用る て薄片內の振動方向 $\mathrm{X}^{\prime}$ 及び $Z^{\prime}$ を吟味するに，第四圖を满足する 結果が得られた。倘透輝石の各光 學的彈性軸老角閃石の夫ふに一致 せしむべき趈轉斬は $\lambda=+3^{\circ}$ ， $\varphi=-2 I^{\circ}$ の方向で，廷轉角は $98^{\circ}$ 。 である。

終に臨み現地調查に際して御指

導を賜り，又本稿を御校閱下された渡邀呚授に深謝の意を表する。

\section{箠 檢 分 析 の 霬 驗 (I)}

(鉆及び䂤素の一䚀檢分析法)

Some experiments on microchemical analyses (I)

A method for microchemical analyses

of lead and arsenic

理學士須 藤 俊 男 (T. Sudô)

內 容
1) 序 言
2）鏡检分析の歷史的瞥見
3) 鉛の鏡检分析

4）吪素の獍检分析

5) 管羷結果

6) 要 旨

\section{1 序需}

鏡檢分析は特殊定性分析の一種であつて，その方法の概略は次の如くで ある。

師ち清淨にされた截物ガラス上に於いて,極く小さい試藥滴の中に(大き 